\title{
STABILISASI TANAH LEMPUNG MENGGUNAKAN SEMEN DAN ASPAL EMULSI TERHADAP SUBGRADE PERKERASAN JALAN
}

\author{
Muhammad Ernadi Ramadhan ${ }^{1, *}$, Suryo Hapsoro Tri Utomo², Latif Budi Suparma ${ }^{3}$ \\ ${ }^{1, *}$ Departemen Teknik Sipil dan Lingkungan, Universitas Gadjah Mada, Yogyakarta \\ Email: muhammad.ernadi.r.@mail.ugm.ac.id \\ ${ }^{2}$ Departemen Teknik Sipil dan Lingkungan, Universitas Gadjah Mada, Yogyakarta \\ Email: suryohapsoro@ugm.ac.id \\ ${ }^{3}$ Departemen Teknik Sipil dan Lingkungan, Universitas Gadjah Mada, Yogyakarta \\ Email: lbsuparma@ugm.ac.id
}

\begin{abstract}
Several causes can cause pavement deterioration; a weak subgrade caused one of them. If the pavement construction was built on the weak subgrade, it could damage pavement construction at the top of the subgrade. Chemical soil stabilization with cement and bitumen emulsion is one of the solutions to improve soil bearing capacity for pavement subgrade construction. The purpose of this study was to analyze the potential use of cement and bitumen emulsion as materials of chemical soil stabilization for pavement subgrade construction. In this study, soil samples were mixed by cement $(3 \%, 6 \%, 9 \%)$ and bitumen emulsion $(3 \%, 6 \%)$ and cured for 0,3 , and 7 days. The mixture of soil, cement, and bitumen emulsion was tested for soil bearing capacity and soil swelling by CBR and soil swelling test based on ASTM D 1883-99. Preliminary test results concluded that the original soil is included in class A-7-5 at the AASHTO classification system, and it is dominated by smectite clay minerals so that the original soil is expansive clay soil. The results of the compaction test reveal that soil stabilization with cement and bitumen emulsion can increase the mass of dry density of the soil. They reduce the optimum moisture content, where the variation of $6 \%$ cement and 3\% bitumen emulsion can increase the mass of dry density by 1,340 $\mathrm{gr} / \mathrm{cm} 3$ and reduce the optimum moisture content of 25\%. The CBR and swelling test also disclose that soil stabilization with cement and bitumen emulsion increases soil bearing capacity and reduce swelling. The highest CBR values (soaked and unsoaked) are found in the variation of $9 \%$ cement and 3\% bitumen emulsion cured by seven days, where the value is $56.9 \%$ (CBR Soaked) and 44.01\% (CBR Unsoaked). The variation of 9\% cement and 3\% bitumen emulsion also can reduce soil swelling, where the value is $0,13 \%$. CBR values at the variety of $9 \%$ cement and $3 \%$ bitumen emulsion cured by seven days have met the requirements of the road pavement subgrade based on SNI 03-1744-1989. Based on these tests, the cement and bitumen emulsion can use for soil stabilization material for subgrade pavement construction.
\end{abstract}

Keywords: Soil stabilization, clay, cement, bitumen emulsion

\section{PENDAHULUAN}

Kekuatan struktur perkerasan sangat bergantung pada kondisi tanah dasar. Banyak kerusakan jalan yang terjadi disebabkan karena kondisi fisik tanah dasar yang kurang baik. Berbagai cara dilakukan untuk meningkatkan kuat dukung tanah dasar, salah satunya yaitu melakukan stabilisasi tanah secara kimiawi. Contoh bahan kimiawi yang umum digunakan untuk stabilisasi tanah yaitu semen dan aspal emulsi. Baik semen maupun aspal emulsi memiliki keunggulan masingmasing. Menurut RRL (1968), Semen dapat memberikan sifat kekakuan kepada tanah, sedangkan aspal emulsi dapat memberikan efek penahan air terhadap tanah. Berdasarkan hal tersebut, maka perlu dilakukan penelitian mengenai stabilisasi tanah lempung 
menggunakan semen dan aspal emulsi terhadap subgrade perkerasan jalan.

Penelitian-penelitian sebelumnya mengenai stabilisasi tanah menggunakan semen dan aspal emulsi telah dilakukan oleh penelitipeneliti terdahulu. Baghini dkk. (2013) melakukan penelitian mengenai potensi penggunaan campuran semen portland dan aspal emulsi pada stabilisasi tanah konstruksi base jalan dan menyimpulkan bahwa penggunaan semen dan aspal emulsi dapat meningkatkan nilai kuat tekan dan modulus elastisitas tanah dengan kadar optimum sebesar 3\% semen dan 3\% aspal emulsi. Susanto (2009) melakukan penelitian mengenai pengaruh stabilisasi tanah lempung dengan aspal emulsi terhadap penurunan konsolidasi dan modulus elastisitas tanah. Hasil penelitian menunjukkan bahwa stabilisasi tanah dengan kadar aspal emulsi optimum sebesar $6 \%$ dapat meningkatkan nilai modulus elastisitas tanah.

Tujuan dari penelitian ini yaitu untuk menganalisis pengaruh penambahan semen dan aspal emulsi terhadap nilai kuat dukung tanah sebagai subgrade konstruksi perkerasan jalan, sehingga didapatkan kadar terbaik campuran semen dan aspal emulsi sebagai bahan stabilisasi tanah yang dapat memenuhi standar subgrade perkerasan jalan yang digunakan.

\section{METODE PENELITIAN}

Penelitian ini menggunakan metode studi eksperimental dengan melakukan percobaan langsung di Laboratorium. Penelitian utama tentang komposisi mineral tanah dilakukan di Laboratorium Mekanika Tanah Fakultas Teknik Departemen Teknik Sipil dan Lingkungan, Universitas Gadjah Mada. Benda uji berupa sampel tanah asli yang kemudian ditambahkan dengan variasi kadar semen dan kadar aspal emulsi yang telah ditentukan berdasarkan penelitian terdahulu.

\section{Bahan Penelitian}

Bahan utama penelitian berupa sampel tanah asli yang berasal dari daerah Krebet, Kecamatan Sentolo, Kabupaten Kulonprogo, Provinsi Daerah Istimewa Yogyakarta. Bahan pencampur yang digunakan pada penelitian ini menggunakan 2 bahan, yaitu semen dan aspal emulsi. Jenis semen yang digunakan pada stabilisasi tanah yaitu Semen Portland merk Semen Gresik, sedangkan jenis aspal emulsi yang digunakan pada stabilisasi tanah yaitu aspal emulsi Cationic slow setting (CSS-1). Hasil uji pendahuluan tanah asli dapat dilihat pada Tabel 1 berikut.

Tabel 1 Karakteristik Tanah Asli

\begin{tabular}{|l|l|c|l|}
\hline No & \multicolumn{1}{|c|}{ Jenis Pengujian } & Satuan & Nilai \\
\hline 1 & Spesific Gravity $(\mathrm{Gs})$ & & 2,63 \\
\hline 2 & Kadar air optimum $\left(\mathrm{w}_{\text {opt }}\right)$ & $\%$ & 29,02 \\
\hline 3 & $\begin{array}{l}\text { Berat volume kering tanah } \\
\text { maksimum }\left(\gamma_{\text {dmaks }}\right)\end{array}$ & $\mathrm{gr} / \mathrm{cm}^{3}$ & 1,29 \\
\hline 4 & Batas cair (Liquid Limit), LL & $\%$ & 73,60 \\
\hline 5 & $\begin{array}{l}\text { Batas plastis (Plastic Limit), } \\
\text { PL }\end{array}$ & $\%$ & 35,98 \\
\hline 6 & $\begin{array}{l}\text { Indeks plastisitas (Plasticity } \\
\text { Index),PI = LL - PL }\end{array}$ & $\%$ & 37,62 \\
\hline 7 & $\begin{array}{l}\text { Batas susut (Shhrinkage } \\
\text { Limit), SL }\end{array}$ & $\%$ & 23,82 \\
\hline 8 & CBR Unsoaked & $\%$ & 11 \\
\hline 9 & CBR Soaked & $\%$ & 0,97 \\
\hline 10 & Swelling & & \\
\hline
\end{tabular}

Berdasarkan hasil penelitian karakteristik dan kandungan mineralogi tanah asli, dihasilkan nilai LL sebesar 73,60\%, PL sebesar 35,98\%, SL sebesar 23,82\%, dan indeks plastisitas (PI) sebesar 37,62\%. Berdasarkan klasifikasi AASHTO, sampel tanah yang digunakan dalam penelitian ini adalah tanah lempung yang termasuk klasifikasi tanah A-7-5. Pengujian mineralogi sampel tanah asli menyimpulkan bahwa tanah asli memiliki kandungan smectite sebesar 73,25\%. Dengan demikian, sampel tanah termasuk dalam jenis tanah lempung ekspansif. Hasil pengujian grain size dapat dilihat pada Gambar 1. 


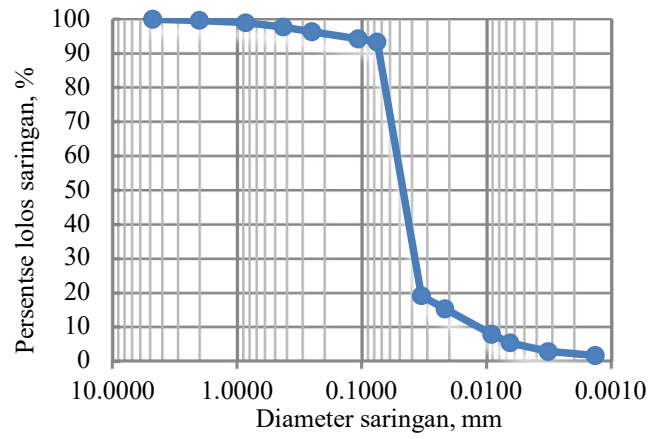

Gambar 1. Grafik pengujian grain size tanah asli

\section{Peralatan Penelitian}

Peralatan penelitian yang digunakan pada penelitian ini yaitu:

1. Satu set alat uji pemadatan tanah (standard Proctor), peralatan yang digunakan pada penelitian ini sesuai dengan standar ASTM D 698-00a. Pengujian pemadatan tanah dilakukan sebanyak 6 sampel pada setiap variasi pencampuran dengan variasi air yang berbeda-beda pada tiap sampel dengan tujuan dapat menentukan nilai kadar air optimum tanah dan nilai berat volume kering tanah maksimum.

2. Satu set alat uji California Bearing Ratio (CBR) laboratorium. Alat yang digunakan untuk uji CBR sesuai dengan standar ASTM D 1883-99. Pengujian CBR dilakukan sebanyak 2 kali untuk tiap variasi pencampuran, yaitu CBR soaked dan unsoaked.

3. Alat uji potensi pengembangan tanah. Alat uji pengembangan tanah menggunakan mold yang sama dengan alat uji CBR yaitu mold dengan diameter 6 inch dan digunakan satu set alat pengujian potensi pengembangan tanah. Pengujian potensi pengembangan tiap variasi pencampuran dilakukan bersamaan dengan pengujian CBR soaked.

\section{Pengujian Penelitian}

Pengujian pada penelitian ini dibagi menjadi 2 bagian, yatu uji pendahuluan dan uji utama.

1. Uji pendahuluan pada penelitian ini meliputi uji identifikasi mineral tanah dan uji sifat fisik dan mekanis tanah asli dengan tujuan dapat mengetahui dan mengidentifikasi jenis tanah yang akan diuji. Uji pendahuluan meliputi uji mineralogi tanah, uji specific gravity, uji batas-batas Atterberg, uji grain size, uji pemadatan standard proctor, dan uji CBR tanah pada tanah asli.

2. Uji utama pada penelitian bertujuan untuk menganalisis perubahan mekanis pada tanah asli terhadap penambahan semen dan aspal emulsi. Pengujian ini meliputi uji pemadatan, uji $C B R$ soaked dan unsoaked, serta swelling tanah campuran semen dan aspal emulsi. Kadar semen yang ditetapkan pada penelitian ini yaitu $3 \%$, 6\%, dan $9 \%$ terhadap berat kering tanah asli, sedangkan kadar aspal emulsi yang ditetapkan pada penelitian ini yaitu $3 \%$ dan $6 \%$ terhadap berat kering tanah asli. Setiap sampel juga diberikan perlakuan waktu pemeraman yang berbeda, yaitu 0 hari, 3 hari, dan 7 hari. Dalam pembuatan benda uji, tanah dicampurkan dengan semen dan aspal emulsi yang telah ditentukan masingmasing kadarnya menggunakan mixer tanah hingga campuran menjadi rata.

Setelah pencampuran tanah dengan semen dan aspal emulsi, campuran tanah kemudian diambil sampel sekitar $2 \mathrm{~kg}$ setiap percobaan untuk dilakukan uji pemadatan tanah. Uji pemadatan dilakukan sebanyak 6 kali dengan kadar air yang berbeda-beda dalam 1 variasi pencampuran tanah untuk menghasilkan kurva pemadatan berdasarkan nilai kadar air optimum tanah dan berat volume kering tanah maksimum

Uji CBR tanah (Gambar 2) dilakukan dengan 2 pengujian, yaitu Uji CBR Soaked dan uji CBR Unsoaked. Campuran tanah diambil 
sampel sekitar 3,5 $\mathrm{kg}$ setiap percobaan CBR tanah untuk 1 variasi pencampuran tanah. Setelah sampel tanah CBR dipadatkan, sampel tanah diperam dengan plastik selama 0 hari, 3 hari, dan 7 hari untuk setiap pengujian CBR. Pengujian potensi pengembangan tanah dilakukan bersamaan dengan pengujian CBR Soaked selama 4 hari.

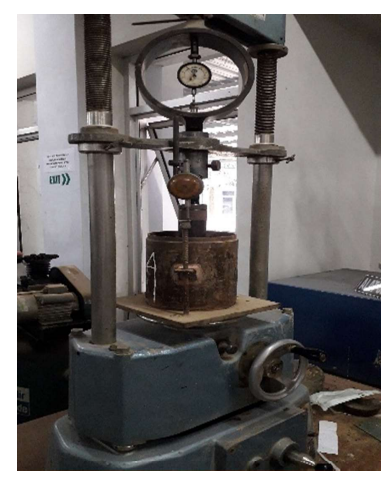

Gambar 2. Pengujian CBR tanah

\section{Metode Analisis}

Pengujian CBR dan swelling tanah dapat dilaksanakan sebagai berikut :

1. Uji CBR soaked dan unsoaked

Perhitungan untuk penetrasi 0,1 inch terhadap tekanan penetrasi standar dapat dihitung dengan Persamaan (1).

$C B R=\frac{P_{1}(p s i)}{1000} \times 100$ (psi)

Perhitungan untuk penetrasi 0,2 inch terhadap tekanan penetrasi standar dapat dihitung dengan Persamaan (2).

$C B R=\frac{P_{2}(p s i)}{1500} \times 100$ (psi)

dengan,

$\mathrm{P} 1$ = tekanan piston pada penetrasi 0,1 inch (psi),

$\mathrm{P} 2$ = tekanan piston pada penetrasi 0,2 inch (psi).

Jika nilai CBR pada penetrasi 0,1 " lebih besar daripada penetrasi 0,2 ", maka nilai CBR yang digunakan yaitu nilai CBR penetrasi 0,1 ". Jika nilai CBR penetrasi 0,2 " lebih besar daripada penetrasi 0,1 ", maka pengujian sebaiknya diulang, namun bila pengulangan pengujian menghasilkan nilai CBR penetrasi 0,2 " tetap lebih besar, maka nilai CBR tersebut digunakan untuk perancangan.

2. Uji swelling tanah

Perhitungan untuk mengetahui nilai swelling tanah dapat ditentukan dengan Persamaan (3).

$s=\frac{\left(h_{2}-h_{1}\right)}{h_{1}} \times 100 \%$

dengan,

$\mathrm{s}$ = swelling,

$\mathrm{h}_{1}=$ tinggi benda uji awal $(\mathrm{mm})$,

$\mathrm{h}_{2}=$ tinggi benda uji akhir $(\mathrm{mm})$.

\section{HASIL DAN PEMBAHASAN}

Pemadatan tanah campuran tanah, semen, dan aspal emulsi

Data kadar air optimum dan berat volume kering tanah maksimum diperoleh dari pengujian pemadatan standard proctor. Hasil pengujian pemadatan dapat diperoleh sebagaimana Gambar 3 dan Gambar 4.

Berdasarkan hasil pengujian pemadatan standard proctor diketahui bahwa penambahan semen dan aspal emulsi pada tanah dapat meningkatkan nilai berat volume kering maksimum campuran terhadap nilai berat volume kering maksimum tanah asli pada setiap variasi campuran tanah dengan semen dan aspal emulsi. Peningkatan terbesar pada variasi kadar semen sebesar $6 \%$ dan kadar aspal emulsi sebesar 3\% dengan nilai $\gamma_{\text {maks }}$ sebesar $13,34 \mathrm{kN} / \mathrm{m}^{3}$. Penambahan semen dan aspal emulsi juga dapat menurunkan kadar air optimum tanah asli. Penurunan kadar air optimum terbesar terdapat pada variasi kadar semen sebesar 6\% dan kadar aspal emulsi sebesar 3\% dengan nilai $\mathrm{w}_{\text {opt }}$ sebesar $25 \%$. Hal ini disebabkan karena adanya pengaruh penambahan semen sehingga dapat mereduksi ronggga pori tanah yang disebabkan adanya proses primer berupa hidrasi dan proses sekunder berupa cation exchange dan pozzolanic. (Ingles dan Metcalf, 1972). Pada proses perubahan kation, ketika semen ditambahkan pada tanah, 
akan terjadi reaksi antara $\mathrm{Ca}(\mathrm{OH})_{2}$ dan mineral lempung. Muatan ion positif yang kuat pada kalsium yang dihasilkan oleh semen akan menggantikan ion yang lemah seperti $\mathrm{Na}^{+}, \mathrm{Mg}^{2+}, \mathrm{K}^{+}$, atau $\mathrm{H}^{+}$, sehingga akan menghasilkan lebih banyak ion kalsium bermuatan positif pada permukaan partikel tanah lempung sehingga dapat mengurangi plastisitas tanah. Reaksi pozzolanik akan menghasilkan reaksi antara $\mathrm{Ca}(\mathrm{OH})_{2}$ dari semen dengan silika dan alumina dari partikel tanah lempung sehingga akan menghasilkan gel yang tersementasi, sehingga dapat meningkatkan kekuatan dan keawetan campuran tanah. Proses karbonasi dapat terjadi pada campuran tanah dengan semen jika semen bereaksi dengan karbon dioksida di atmosfir, sehingga akan menghasilkan kalsium karbonat (Zumrawi, 2015).

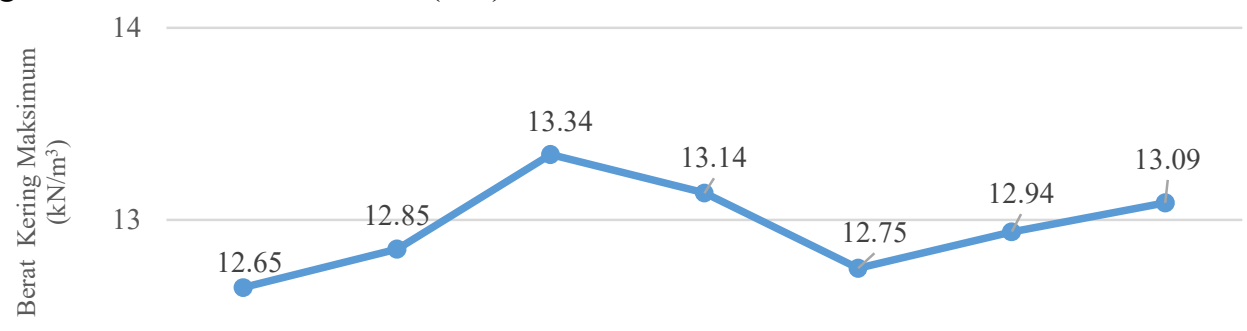

\footnotetext{
12
}

$$
\begin{array}{ccccccc}
\text { Tanah Asli } & 3 \% \text { Semen }+ & 6 \% \text { Semen } & 9 \% \text { Semen } & \text { 3\% Semen }+ & 6 \% \text { Semen }+ & 9 \% \text { Semen }+ \\
& 3 \% \text { Aspal } & 3 \% \text { Aspal } & 3 \% \text { Aspal } & 6 \% \text { Aspal } & 6 \% \text { Aspal } & 6 \% \text { Aspal } \\
\text { Emulsi } & \text { Emulsi } & \text { Emulsi } & \text { Emulsi } & \text { Emulsi } & \text { Emulsi } \\
& \multicolumn{2}{l}{\text { Variasi Kadar Campuran Semen dan Aspal Emulsi }} &
\end{array}
$$

Gambar 3. Grafik nilai berat volume kering maksimum tanah

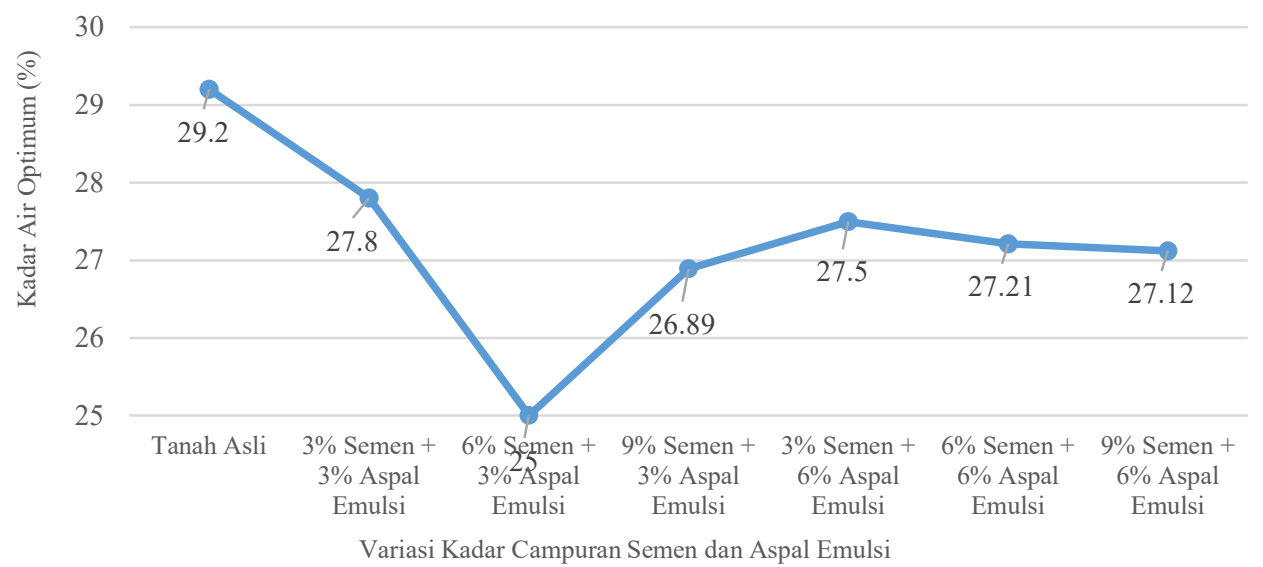

Gambar 4. Grafik nilai kadar air optimum

Selain itu, pengaruh penambahan aspal emulsi pada tanah dapat menyebabkan aspal emulsi mengalami proses breaking oleh pengaruh agregat pada tanah sehingga aspal dapat menempel pada tanah dan dapat memberikan efek penahan air pada tanah. Hal ini disebabkan karena pada umumnya agregat atau material tanah memiliki kandungan listrik negatif di permukaannya, sehingga ion aspal emulsi yang bersifat kationik akan tertarik oleh muatan negatif pada material tanah (Nugroho, 2003). Pada proses breaking, aspal akan berpisah dengan air, kemudian air dari proses breaking aspal emulsi akan diikat 
oleh semen sebagai bagian dari proses hidrasi. Adanya proses flokulasi yang menyebabkan butiran tanah menjadi lebih besar dari pencampuran tanah, semen, dan aspal emulsi sehingga dapat meningkatkan berat volume kering tanah dan menurunkan kadar air optimum tanah. Pada pengujian pemadatan ini, nilai terbesar terdapat pada variasi $6 \%$ semen dan 3\% aspal emulsi. Hal ini disebabkan karena proses sementasi yang memperkuat ikatan antar partikel tanah, semen, dan aspal menjadi sempurna membutuhkan waktu yang lebih cepat dibandingkan dengan penambahan semen sebesar 9\% terhadap campuran tanah, semen, dan aspal emulsi, sehingga untuk mendapatkan hasil yang memuaskan, variasi penambahan semen sebesar $9 \%$ terhadap campuran tanah, semen, dan aspal emulsi harus dilakukan pemeraman terlebih dahulu.
Namun pada variasi penambahan kadar aspal emulsi sebesar $6 \%$ cenderung dapat menurunkan berat volume kering maksimum tanah. Hal ini disebabkan karena jumlah kandungan air pada tanah menjadi berlebih akibat adanya tambahan air pada aspal emulsi, sehingga dapat mengurangi kepadatan pada tanah dan akan mengurangi berat volume kering maksimum tanah dan dapat meningkatkan kadar air optimum dalam tanah (Baghini et al, 2015).

\section{CBR tanah campuran semen dan aspal emulsi}

Pengujian CBR pada variasi campuran tanah, semen, dan aspal emulsi dilakukan pada kondisi soaked dan unsoaked dengan perlakuan pemeraman 0 hari, 3 hari, dan 7 hari. Hasil pengujian CBR untuk kondisi soaked dan unsoaked dapat dijelaskan pada Gambar 5 dan Gambar 6.

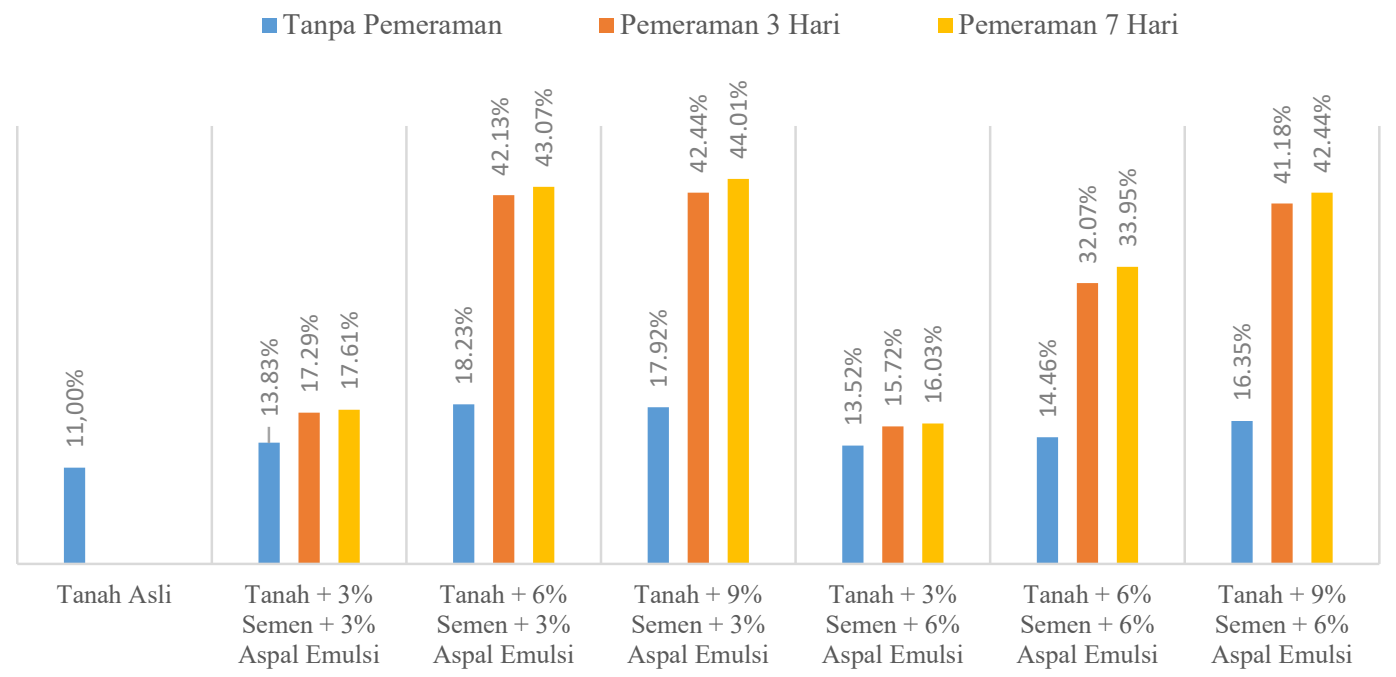

Gambar 5. Hasil pengujian CBR unsoaked tanah campuran semen dan aspal emulsi

Peningkatan pada nilai CBR unsoaked tersebut disebabkan karena adanya proses hidrasi, pertukaran kation, dan reaksi pozzolanic pada proses sementasi yang akan menghasilkan tobermorite yang masuk ke dalam rongga pori dan kemudian mengikat partikel tanah dan didukung dengan proses karbonasi yang akan membentuk material tersementasi sehingga dapat meningkatkan ikatan antar butiran tanah. Selain itu, pengaruh penambahan aspal emulsi pada tanah dapat menyebabkan aspal emulsi mengalami proses breaking oleh pengaruh agregat pada tanah sehingga aspal dapat menempel pada tanah dan dapat memberikan efek penahan air pada tanah. Hal ini 
disebabkan karena pada umumnya agregat atau material tanah memiliki kandungan listrik negatif di permukaannya, sehingga ion aspal emulsi yang bersifat kationik akan tertarik oleh muatan negatif pada material tanah (Nugroho, 2003). Pada proses breaking, aspal akan berpisah dengan air, kemudian air dari proses breaking aspal emulsi akan diikat oleh semen sebagai bagian dari proses hidrasi. Adanya proses flokulasi yang menyebabkan butiran tanah menjadi lebih besar dari pencampuran tanah, semen, dan aspal emulsi. Ketika tanah campuran semen dan aspal emulsi dipadatkan, partikel-partikel tanah akan saling mengunci, sehingga tanah akan menjadi lebih rapat dan dapat meningkatkan nilai CBR tanah. Namun pada variasi penambahan kadar aspal emulsi sebesar $6 \%$ terhadap campuran tanah dan semen cenderung dapat menurunkan nilai CBR pada tanah. Hal ini disebabkan karena jumlah kandungan air pada tanah menjadi berlebih akibat adanya tambahan air pada aspal emulsi, sehingga interlocking antar partikel tanah menjadi berkurang yang menyebabkan kepadatan tanah menjadi berkurang nilainya. Nilai CBR unsoaked terbesar terdapat pada variasi kadar 9\% semen dan 3\% aspal emulsi dengan waktu pemeraman 7 hari sebesar $44,01 \%$.

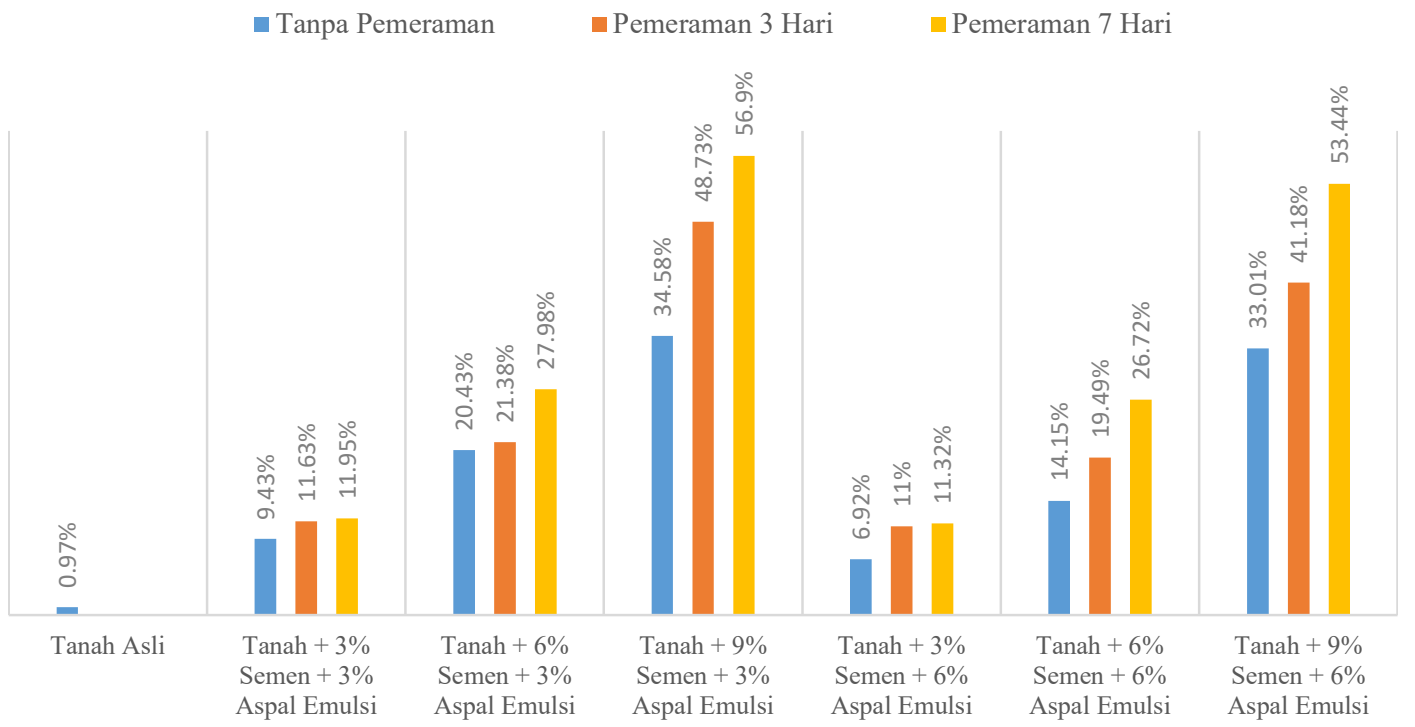

Gambar 6. Hasil pengujian CBR soaked tanah campuran semen dan aspal emulsi

Sama halnya dengan kondisi tanpa perendaman, penambahan variasi kadar semen dan aspal emulsi dapat meningkatkan nilai CBR tanah asli, baik pada kondisi tanpa pemeraman, dengan pemeraman 3 hari, dan dengan pemeraman 7 hari. Penyebab peningkatan nilai $\mathrm{CBR}$ terendam sama dengan kondisi tanpa perendaman, namun yang menarik pada penelitian ini yaitu setelah dilakukan perendaman, nilai CBR pada variasi kadar 9\% semen (baik dengan penambahan 3\% aspal emulsi maupun $6 \%$ aspal emulsi) lebih meningkat terutama setelah dilakukan pemeraman terlebih dahulu. Kondisi ini disebabkan karena proses hidrasi yang dialami oleh jumlah semen yang lebih banyak, kemudian diikuti dengan proses pertukaran ion, pozzolanic yang memicu proses flokulasi dan aglomerasi serta didukung oleh proses karbonasi dan perekatan aspal emulsi pada tanah sehingga akan memperkuat ikatan butian tanah. Yoder dan Witzcak (1975) menyatakan bahwa campuran semen dengan tanah mendapatkan kekuatan 
dalam waktu yang relatif singkat. Air tidak akan mengintrusi ke dalam butiran campuran dan mengganggu proses sementasi, namun dapat berperan dalam curing proses sementasi. Nilai CBR unsoaked terbesar terdapat pada variasi kadar 9\% semen dan 3\% aspal emulsi dengan waktu pemeraman 7 hari sebesar $56,97 \%$.

\section{Swelling tanah campuran semen dan aspal emulsi}

Pengaruh penambahan variasi campuran kadar semen dan aspal emulsi terhadap tanah asli cenderung dapat menurunkan nilai pengembangan tanah asli. Namun pada kondisi tanpa pemeraman, nilai swelling cenderung meningkat (Gambar 7) seiring dengan penambahan semen dan aspal emulsi.

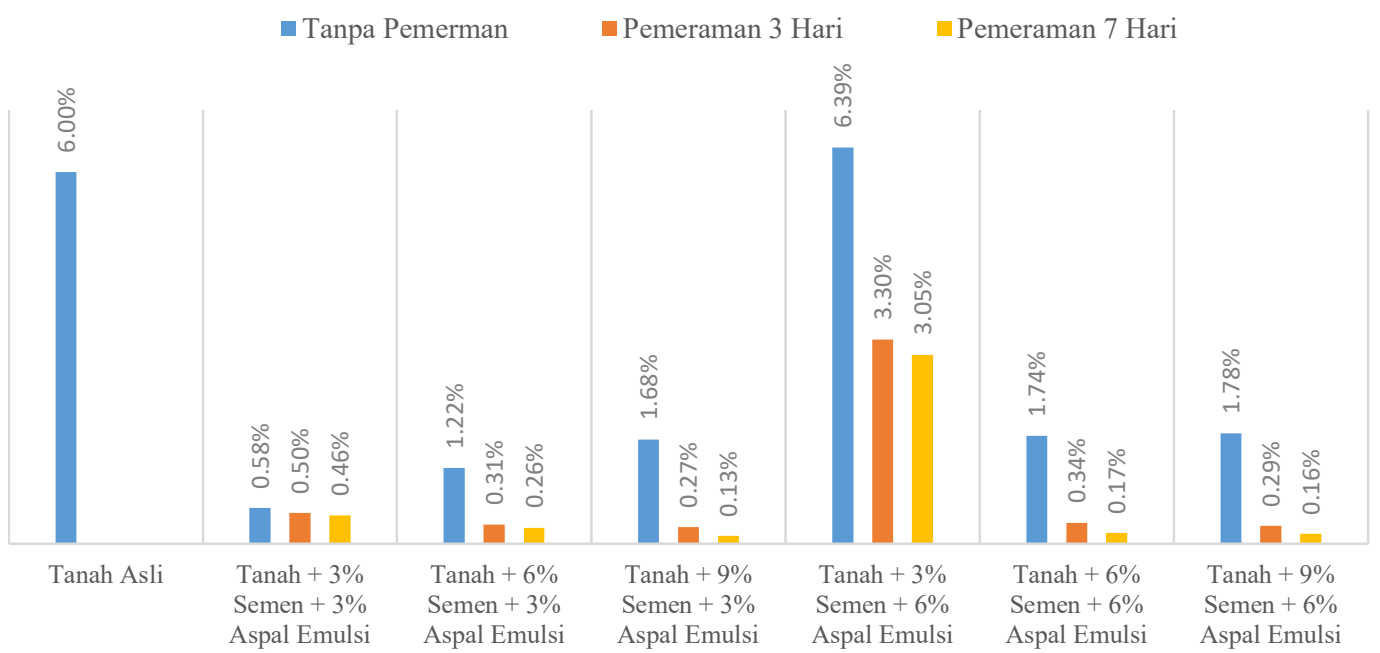

Gambar 7. Hasil pengujian swelling tanah campuran semen dan aspal emulsi

Hal tersebut terjadi karena belum sempurnanya reaksi kimia yang terjadi pada campuran tanah dan semen sehingga partikel air dapat mengintrusi tanah. Selain itu, peningkatan jumlah semen akan membutuhkan air yang lebih banyak dalam proses hidrasi dan kadar aspal emulsi yang berlebihan menyebabkan nilai pengembangan tanah menjadi lebih besar. Namun pada kondisi pemeraman 3 hari dan pemeraman 7 hari, nilai swelling cenderung menurun.

Hal ini terjadi karena proses ikatan antar partikel tanah, semen, dan aspal menjadi sempurna selama masa pemeraman. Hal tersebut menyebabkan air menjadi sulit untuk masuk ke dalam partikel tanah sehingga volume tanah cenderung sulit berubah dan nilai swelling cenderung menurun. Swelling pada kondisi pemeraman akan lebih kecil jika dibandingkan dengan kondisi tanpa pemeraman akibat proses sementasi yang sempurna dan proses setting aspal emulsi pada tanah menyebabkan ikatan antara partikel tanah, semen, dan aspal emulsi menjadi lebih kuat, sehingga sulit ditembus oleh air dan dapat menurunkan nilai swelling tanah. Nilai swelling terkecil terdapat pada variasi kadar 9\% semen dan 3\% aspal emulsi dengan waktu pemeraman 7 hari sebesar $0,13 \%$.

\section{Penentuan kadar terbaik campuran semen dan aspal emulsi}

Berdasarkan pada pengujian pemadatan, CBR, dan swelling tanah, maka dapat disimpulkan bahwa kadar terbaik campuran semen dan aspal emulsi sebagai bahan stabilisasi tanah lempung terdapat pada variasi penambahan $9 \%$ semen dan 3\% aspal emulsi dengan pemeraman 7 hari. Menurut Spesifikasi Umum Bina Marga 2010 Revisi 3 
dalam Pratama (2018) menyatakan bahwa persyaratan nilai CBR tanah dasar sesuai dengan pengujian CBR Laboratorium adalah memiliki nilai minimal $6 \%$ setelah direndam 4 hari Dengan demikian, nilai CBR pada variasi penambahan $9 \%$ semen dan 3\% aspal emulsi telah memenuhi persyaratan subgrade perkerasan jalan.

\section{KESIMPULAN}

1. Penambahan campuran variasi kadar semen sebesar 3\%, 6\%, 9\%, dan aspal emulsi sebesar $3 \%$ dan $6 \%$ dapat meningkatkan berat volume kering tanah maksimum dan menurunkan kadar air optimum pada tanah asli. Peningkatan berat volume kering tanah maksimum dan penurunan kadar air optimum terbesar terdapat pada kadar $6 \%$ semen dan 3\% aspal emulsi dimana nilai berat volume kering tanah maksimum sebesar 13,34 $\mathrm{kN} / \mathrm{m}^{3}$ dan nilai kadar air optimum sebesar $25 \%$.

2. Penambahan campuran variasi kadar semen dan aspal emulsi cenderung meningkatkan nilai CBR unsoaked, CBR soaked, dan menurunkan nilai swelling pada tanah asli seiring dengan penambahan kadar semen dan aspal emulsi dalam campuran tanah. Peningkatan terbesar nilai CBR baik CBR unsoaked maupun CBR soaked serta penurunan terbesar nilai swelling tanah terdapat pada variasi campuran $9 \%$ semen dan 3\% aspal emulsi dengan pemeraman 7 hari. Nilai CBR unsoaked dan CBR soaked masingmasing sebesar $44,01 \%$ dan $56,97 \%$, sedangkan nilai swelling pada pengujian tersebut sebesar $0,13 \%$.

3. Berdasarkan Spesifikasi Umum Bina Marga 2010 Revisi 3 dalam Pratama (2018) menyatakan bahwa persyaratan nilai CBR tanah dasar sesuai dengan pengujian CBR laboratorium memiliki nilai minimal $6 \%$ setelah direndam 4 hari. Dengan demikian, nilai CBR pada variasi penambahan $9 \%$ semen dan $3 \%$ aspal emulsi telah memenuhi persyaratan subgrade perkerasan jalan.

\section{DAFTAR PUSTAKA}

ASTM D1883-99. (1999). "Standard Test Method for CBR (California Bearing Ratio) of Laboratory-Compacted Soils". ASTM International. West Conshohocken, PA.

ASTM D 698-00a. (2000). "Standard Test Method for Laboratory - Compaction Charasteristics of Soils Using Standard Effort”. ASTM International. West Conshohocken, PA.

Baghini, M. S., Ismail, A., dan Kheradmand, B. (2013). "The Potentials of Portland Cement and Bitumen Emulsion Mixture on Soil Stabilization in Road Base Construction". Jurnal Teknologi (Sciences \& Engineering) .Vol. 65.No.2, pp 67-72.

Baghini, M.S., Ismail, A., dan Karim, M.R.B., (2015). "Evaluation of Cemet-Treated Mixtures with Slow Setting Bitumen Emulsion as Base Course Material for Road Pavement". Journal of Construction and Building Materials. Volume 94, pp 323-336.

Ingles, O.G., and Metcalf, J.B. (1972). "Soil Stabilization-Principles and Practice". Sydney, Melbourne, Brisbane: Butterworths.

Nugroho, U. (2003). "Pengaruh Penambahan Kapur dan Aspal Emulsi Terhadap Kembang Susut dan Daya Dukung Tanah Ekspansif Sebagai Subgrade Jalan". Tesis. Program Pascasarjana Universitas Diponegoro. Semarang Tidak dipublikasikan

Pratama, F. (2018). "Stabilisasi Tanah Lempung Ekspansif Dengan Menggunakan Kapur dan Portland Composite Cement Pada Tanah Dasar Konstruksi Jalan". Tesis. Teknik Sipil. Universitas Gadjah Mada: Tidak dipublikasikan 
ISSN 0853-8557

Road Research Laboratory. (1968). "Soil Mechanics for Road Engineer". London: H.M. Stasionery Office.

Yoder E.J dan Witczak M.W. (1975). "Principles of Pavement Design" Second Edition. New York: John Wiley \& Son Inc.
Zumrawi, M., (2015). "Stabilization of Pavement Subgrade by Using Fly Ash Activated by Cement". American Journal of Civil Engineering and Architecture, Vol. 3, No 6, pp 218-22. 